\title{
Rendered Agroecosystem Services and Dysservices of Dairy Farming: A Bottom-Up Approach in Galicia (Spain)
}

\author{
Ibán Vázquez-González *DiD, María do Mar Pérez-Fra (D), Ana Isabel García-Arias, Bernardo Valdês-Paços \\ and Edelmiro López-Iglesias $\mathbb{D}$
}

ECOAGRASOC - Department of Applied Economics, University of Santiago de Compostela, 15782 Santiago de Compostela, Spain; mariadomar.perez@usc.es (M.d.M.P.-F.); anaisabel.garcia@usc.es (A.I.G.-A.); bernardo.valdes@usc.es (B.V.-P.); edelmiro.lopez@usc.es (E.L.-I.)

* Correspondence: iban.vazquez.gonzalez@usc.es; Tel.: +34-982-823-224

Citation: Vázquez-González, I.; Pérez-Fra, M.d.M.; García-Arias, A.I.; Valdês-Paços, B.; López-Iglesias, E. Rendered Agroecosystem Services and Dysservices of Dairy Farming: A Bottom-Up Approach in Galicia (Spain). Sustainability 2021, 13, 8509. https://doi.org/10.3390/su13158509

Academic Editor: Andrea Colantoni

Received: 8 July 2021

Accepted: 28 July 2021

Published: 29 July 2021

Publisher's Note: MDPI stays neutral with regard to jurisdictional claims in published maps and institutional affiliations.

Copyright: (C) 2021 by the authors. Licensee MDPI, Basel, Switzerland. This article is an open access article distributed under the terms and conditions of the Creative Commons Attribution (CC BY) license (https:/ / creativecommons.org/licenses/by/ $4.0 /)$.

\begin{abstract}
Humans have traditionally sought provisioning services from rural areas, but society is becoming increasingly aware of other services that rural areas provide to human beings, agroecosystem services. At the same time, however, certain dysservices can be identified. The analysis of agroecosystem services and dysservices is a key point to consider in decision-making processes and provides a tool for acting on sustainability. Notwithstanding, few approaches to the dairy sector exist with this focus, and they often do not incorporate the vision of the actors from the entire value chain. The aim of the present paper is to identify agroecosystem services and dysservices deriving from the dairy farming in Galicia (Spain), as perceived by actors linked to this sector. The methodology followed a bottom-up approach (Focus Group) and identified 19 agroecosystem services (S) and 9 dysservices (D) grouped into four main categories: provisioning (6S/0D), environmental quality (5S/5D), rural vitality (6S/2D), and cultural heritage and quality of life (2S/1D). The results show strong awareness of services and dysservices, in particular as regards rural vitality (mainly related to employment and income generation) and environmental services (dyservices linked to intensive systems). We have, however, detected a significant gap in awareness of certain classical environmental services (carbon sequestration of pastures). Finally, one of the innovative findings is the identification of rural vitality services and dysservices, including the social role that farming plays in consolidating the population in rural areas, and in preserving local traditions and culture.
\end{abstract}

Keywords: agroecosystem services; agroecosystem dysservices; Galicia; dairy farming; dairy value chain; focus group; rural vitality

\section{Introduction}

Dairy production is one of the main agricultural activities across the European countries. At the same time, is one of the most intensified and industrialized with important impacts on territory and environment [1,2]. A more sustainable way of offering dairy products is needed and for doing that, all the stakeholders along the value chain must react. As a first step towards the definition of strategies to address a sustainable way of production, we look for identifying the key aspects regarding sustainability that stakeholders recognize. An interesting tool helping this aim is the concept of agroecosystem services and dysservices. Dairy farming can be seen as an agroecosystem. In Galicia, dairy farming has reshaped the territory and landscape as well as the economy of rural areas in a significant way [3-5].

Agroecosystems have been defined as artificial ecosystems [6] where society and the natural ecosystem meet $[7,8]$ and where farmers continuously reproduce and reshape, diminish, or improve the natural capital $[6,9]$ through the specific interactions and mutual transformation of humans and living nature [10]. It is here where the trade-offs involved in land use scenarios often occur; for instance, scenarios that maximize biodiversity conservation and ecosystem services versus scenarios that maximize profit from a commodity [11]. 
Humans have traditionally sought provisioning services from rural areas, such as food, fiber, minerals, timber, etc., yet over time, society has also come to demand regulating and cultural services from these same areas. At the same time, an increase in productivity favored by industrial farming has created a wide range of negative externalities (harm) for both natural and human assets in rural areas [2]. The concept of ecosystem services was developed in the 1990s [12-14], based on earlier concerns regarding the relationship between society and the environment in the late 1970s. It starts with the utilitarian framing of beneficial ecosystem functions as services to increase public interest in biodiversity conservation $[15,16]$. Now, following the publication of the Millennium Ecosystem Assessment (MEA) by the United Nations in 2000 [17], ecosystem services are defined as the benefits that people obtain from ecosystems $[13,16]$. The UN assessment focuses on the linkages between ecosystems, including agroecosystems, and human well-being. It is a suitable framework for exploring the benefits that can be derived from ecosystems, and it has even been reviewed [18,19], as well as the negative effects, known as dysservices [20-23]. Shackelton et al. [23] define ecosystem dysservices as the ecosystem-generated functions, processes and attributes that result in perceived or actual negative impacts on human well-being.

At the same time, the assessment provides a tool for analyzing and acting on sustainability, since the concept of sustainable development implies the recognition of the importance of preserving all kinds of assets—natural, human, constructed, and social-for present and future generations [13] by focusing on three dimensions: natural, economic, and social. This approach concedes that humans, with their cultural diversity, are an integral component of many ecosystems. Ecosystem services are also the vehicle through which natural assets interact with human well-being [13]. The analysis of trade-offs is another key point to consider in decision-making processes.

Despite difficulties derived from using the ecosystem services framework for the analysis of sustainability [24], some authors have recently focused on the approach of ecosystem services to analyze sustainability in livestock agroecosystems [11,25-27]. Most have identified the ecosystem services provided by livestock, especially for extensive livestock systems and pasture-based livestock farming systems in Europe, but few have done this for dairy systems [25,28-30], and as far as we know none has addressed the agroecosystem services identification by stakeholders into the value chain. The present work adopts a bottom-up approach when it aims to identify the perceptions of stakeholders about, not only agroecosystem services rendered by dairy production, but about the perception of dysservices as well. Due to their high degree of industrialization, it is supposed that dairy systems are responsible for several externalities or negative impacts on nature [1], which we can identify as dysservices. The adoption of this last concept is not neither frequent in the literature (11).

As regards the sustainability of livestock systems, most of the literature has focused on the natural dimension of the concept, dealing with practices and strategies to minimize environmental impacts or to enhance biodiversity and landscape preservation [31]. One of the difficulties in adapting the MEA framework to the study of sustainability is the appraisal of the social dimension. Even if this dimension could be approached through the lens of cultural ecosystem services, little of the existing literature on ecosystem services identifies cultural services provided by livestock systems [26]. Moreover, very few studies have considered the economic and social dimensions of sustainability [11,32]. Ryschawy et al. [11] state that insufficient knowledge of the complete set of social contributions from livestock farming, coupled with an excessively environmental focus regarding contributions, limits the scope of livestock sustainability assessments. Consequently, these authors adopt a broader vision than the perspective provided by the MEA [17], including social aspects such as rural vitality, which is defined as "maintaining the social fabric of rural areas through the creation of agricultural and supply chain employment." This proposal treats livestock systems as an agroecosystem through which farms and farmers provide goods and services to society. According to Lynch et al. [33], a better-adapted classification of 
services delivered by livestock systems would be provisioning, environmental, cultural, and rural vitality services. The present work adopts this approach to dairy farming in Galicia for the first time. Few works before have applied the concept of agroecosystem services to livestock in this region but considering only environmental services.

Ryschawy et al. [11] assert that the regional level is often more appropriate than the farm level for determining the contributions of different livestock sectors and the provision of different goods and services in a given location. This same assertion is made by Swagemakers et al. [25] regarding the contribution of farm practices to sustainability, suggesting that the focus should not be strictly limited to the concept of "local", but rather should be conceptualized in terms of "activity space". The concept of activity space would include all actors (animate and inanimate) that define the farm and its trajectory, considering socio-spatial connections for production and consumption such as markets and regional policy frameworks.

Finally, the MEA framework and much of the literature on ecosystem services justify the adoption of this anthropocentric approach to the need for integrating sustainability issues, especially those related with the environmental dimension, in decision-making processes through valuation $[13,34]$. The first step when addressing these issues is to identify the related services and dysservices. This would provide information to stakeholders and society on the multiple benefits and dysservices provided by livestock and would help actors in the livestock sector to better understand and manage sustainability issues [35-37]. Limited research has focused on the study of the effects of specific agricultural practices and management regimes on agroecosystem services and related sustainability issues, as perceived by stakeholders $[11,25,30,36,38]$.

The aim of this paper is to identify ecosystem services and dysservices deriving from the dairy agroecosystem in Galicia (Spain), through a bottom-up approach perceived by local actors linked to the dairy sector. It might find key aspects to better understand the impact of dairy farming on the territory and address sustainable production. According to Ryschawy et al. [11], four main categories of agroecosystem services and dysservices were considered: provisioning (e.g., food quantity and quality), environmental quality (e.g., biodiversity, landscape heterogeneity, water quality), rural vitality (e.g., employment, rural dynamism), and cultural heritage and quality of life (e.g., gastronomy and landscape heritage).

\section{Materials and Methods}

\subsection{Study Area}

Galicia is an autonomous region in the northwest of Spain with an area of $29,574 \mathrm{~km}^{2}$ (Figure 1). Agriculture accounted for 3.2\% of gross value added for the Galician economy in 2019, a significant figure as compared to other European regions. Agriculture, together with the food industry, constitutes one of the most relevant value chains in Galicia, especially in inland areas. The modernization of agriculture has resulted during the last decades in the disappearance of a significant number of farms, a decrease in the utilized agricultural area (UAA) managed by farms, and a process of land abandonment $[4,39]$. The increasing volume of abandoned and forested land has considerable consequences in terms of economic and environmental sustainability due to wildfires, one of the most urgent environmental problems in Galicia [40].

In recent decades, the Galician dairy sector has shown significant production growth. In a context of accelerated restructuring, the number of dairy farms dropped from the approximately 100,000 existing when Spain became part of the European Community (1986), to just over 7100 in December 2019. During this time, dairy production in the region increased by $75 \%$, while the rest of the country saw an overall decrease. As a result, the share of Spanish milk production generated in Galicia rose significantly from $26.9 \%$ in 1985 to $38.9 \%$ in 2019 . The dynamism in recent decades has not only made it possible to consolidate the position as the top producing region in Spain; Galicia is now among the top ten dairy-producing regions in the EU [41]. 


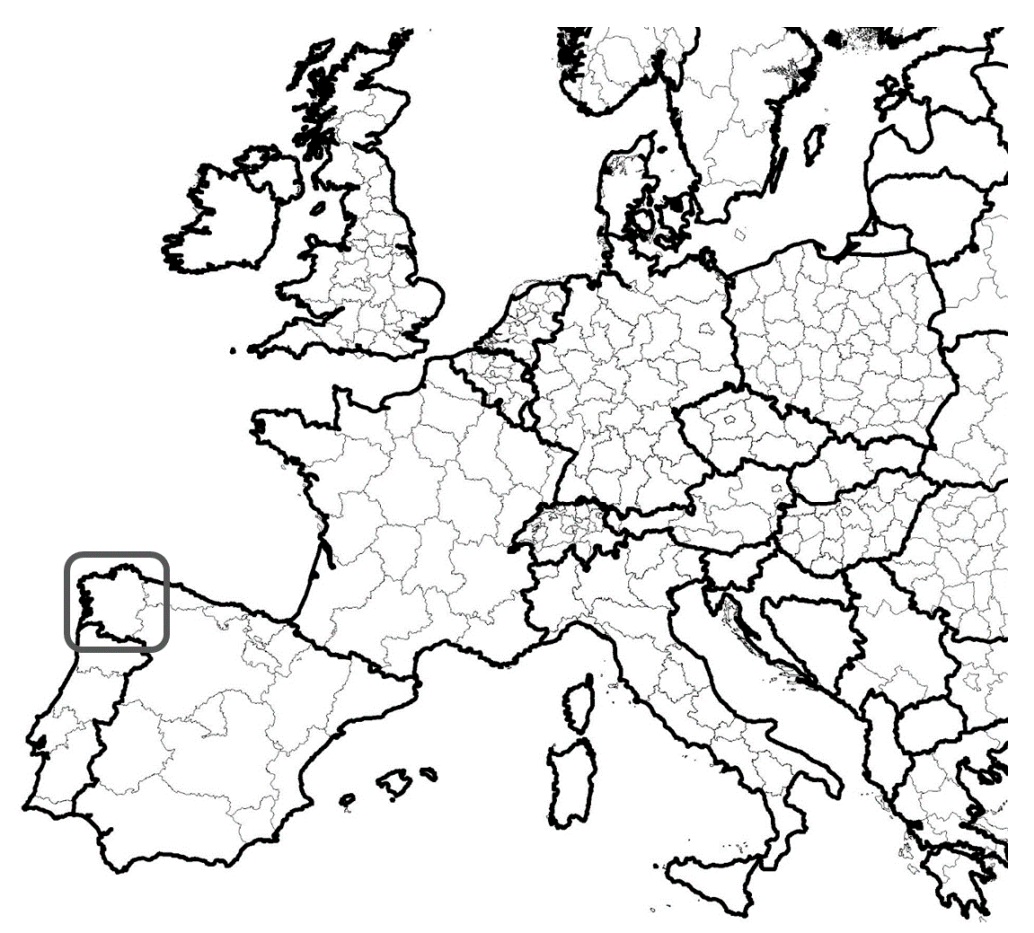

Figure 1. Location of Galicia.

Dairy production is now firmly established as the main specialization of the Galician agricultural sector, contributing with $23.8 \%$ of agricultural production value in 2018 . According to data from the Farm Structure Survey 2016 [42], Galicia had 8462 specialized dairy farms, $11 \%$ of the total farms, which own $29.5 \%$ of UAA, employ $18.1 \%$ of Annual Work Units (AWU), and generate $38 \%$ of total Standard Output of the agricultural sector.

The increase in dairy production has been accompanied by a herd concentration and increase in production for larger, specialized farms, while the share of production from smaller, diversified farms has decreased. According to data from the Cattle Holding Register, dairy farms with 100 or more cows (22.4\% of the total) housed $53.1 \%$ of the total dairy cows [43]. On the other end of the scale, farms with fewer than 50 heads, representing nearly half of the total number of dairy farms, only account for less than $20 \%$ of milk cows, although they still maintain an important position from a social, territorial, and environmental standpoint.

The increase in dairy production at larger farms over the past three decades is not reflected in a similar increase in land area, however, but rather has been achieved largely through intensification of production methods, as shown by an increase in livestock density and dairy production per hectare. This trend has been accompanied by changes in land uses, with an expansion of land used for growing fodder [44]. As a result, while production has increased, the UAA managed by dairy farms has shrunk considerably, and is concentrated in an increasingly smaller area of the Galician territory.

In broad terms, we can distinguish two types of production models in the Galician dairy sector $[3,45]$. The first, more closely linked to land area, includes smaller farms that graze their cattle, obtaining between 5000 and 10,000 L of milk per hectare of UAA. This group includes a larger proportion of older farmers without family members who will continue their work. The second, which includes the majority of medium and large-sized farms, is more intensive, with a production of $>15,000 \mathrm{~L} / \mathrm{ha}$. These farms dedicate a large portion of their area to forage maize crops and use a complete feed ration. In recent years, a new group has emerged: the organic dairy farms. The number of organic dairy farms has tripled in response to the significant rise in the price of organic milk, surpassing 100 farms in 2018. Notwithstanding, the weight of these farms in the overall production continues to be marginal. 


\subsection{Services and Dysservices}

According to Ryschawy et al. [11], in order to classify agroecosystem services, we consider provisioning goods and services to be material and nutritional outputs from the dairy value chain. Environmental services include benefits such as the conservation of biodiversity, climate regulation and water purification, among others. Cultural heritage and quality of life services provided by the dairy sector comprise recreational considerations, and aesthetic and heritage benefits. Finally, rural vitality services include the contribution of dairy farming to maintaining a rural network and creating employment (e.g., farms, supply chain).

We use the same classification to identify dysservices. Zabala et al. [27] state that trade-offs between services and dysservices are expected within an agroecosystem and are influenced by pressures. Agricultural practices represent the main human pressure on an agroecosystem. The outputs may be services or dysservices depending on the intensity of pressure $[27,46]$. We consider provisioning dysservices to be negative impacts on agroecosystem provisioning services, such as lower food quality. Environmental dysservices are negative impacts on agroecosystem regulation services, such as soil erosion. Cultural dysservices include the loss of cultural services, such as loss of landscape. Finally, rural vitality dysservices can be understood as negative impacts on rural social and economic networks.

\subsection{Focus Group}

Focus groups (FG) are open-ended, indirect, qualitative research techniques used to address different aspects of a subject in detail. FGs are based on group discussions, which may or may not be statistically representative, but which do include representatives from different social groups involved in or affected by the issue under discussion [47]. The purpose of these groups is to generate discussion and prompt responses that cover both shared and conflicting ideological views [36]. The recommended number of participants for a profitable and dynamic FG is between 5 and 15 individuals $[48,49]$. In terms of group make-up, there must be a minimum degree of uniformity in order to maintain group symmetry, as well as certain diversity in order to ensure different perspectives that are essential to any discussion process. The FG facilitator plays a crucial role in managing group processes and tasks, while the moderator guides group discussion to address specific research objectives [50]. The moderator will encourage all participants to speak (and may sometimes need to give the floor to others if a particular participant is talking too much), such that the conversation (not debate) will encourage participants to voice group ideologies (shared beliefs, resistance, desires, fears, etc.) with the aim of discussing in detail certain underlying issues and concepts that may be difficult to define.

Our research is based on an FG, organized as part of a European research project ("Propagating innovations for more resilient dairy farming in the Atlantic Area" (Dairy-4Future), funded by the Interreg Atlantic Area Program (EAPA_304/2016)., where every partner follows the same methodology across the different case studies. In addition, this technique is a well stablished qualitative method applied in relevant studies with similar purposes [36,51]. The aim of the FG, held in the Galician city of Lugo in 2019, was to obtain a shared vision on the sustainability of the Galician dairy sector by different local actors. To deal with the different, even opposite, perceptions of stakeholders into the dairy value chain about services and dysservices, the use of FG is adequate since it allows to know perceptions and opinions about a define environment [52]. The dynamics set up into the FG stimulated participants to share experiences and minimize individual bias [53]. Thirteen agents responding to the typology found in Table 1 were selected, with a view to obtain a complete representation of dairy sector stakeholders: two dairy farmers (one extensive, and one intensive), three technicians (research institution, administration, and agricultural co-op), one representative from the dairy industry, one representative from the local administration, one member of a rural development group, two academics (Agricultural Engineering (USC), Centro de Promoción Rural (Escola Fonteboa)), one 
member of the Galician territorial custody network, and two from other bodies (agricultural co-op, association of Holstein Friesian breeders). Three facilitators, one project coordinator and one moderator participated in the session.

Table 1. Focus group composition.

\begin{tabular}{|c|c|c|c|}
\hline Type of Participants & Number $\left(\mathrm{N}^{\circ}\right)$ of Participants & Gender ( $\mathbf{N}^{\circ}$ Male) & Age $\left(\mathrm{N}^{\circ} \leq 40\right.$ Years $)$ \\
\hline Farmers & 2 & 2 & 1 \\
\hline Technicians/technical support & 3 & 2 & 2 \\
\hline Agri-food industry & 1 & 1 & 0 \\
\hline $\begin{array}{l}\text { Municipalities/local communities } \\
\text { and administrations }\end{array}$ & 1 & 0 & 0 \\
\hline Rural development group & 1 & 1 & 0 \\
\hline $\begin{array}{l}\text { Universities/centers for } \\
\text { agricultural education }\end{array}$ & 2 & 1 & 0 \\
\hline NGOs & 1 & 1 & 0 \\
\hline $\begin{array}{c}\text { Cooperatives and farmers' } \\
\text { organizations }\end{array}$ & 2 & 2 & 1 \\
\hline TOTAL & 13 & 10 & 4 \\
\hline
\end{tabular}

The session was structured into five segments (Table 2), for a total duration of four hours, plus a half-hour break. The first segment $(30 \mathrm{~min})$ was an icebreaker for all participants and FG organizers. The purpose of the second segment (55 min) was to identify strengths, weaknesses, opportunities and threats (SWOT analysis) for the dairy sector in Galicia from the standpoint of sustainability.

Table 2. Structure of group dynamics (segments, description, components, and duration).

\begin{tabular}{|c|c|c|c|}
\hline Segment & Description (Actions) & Components & Total Duration (Minutes) \\
\hline 1-Introductions/Icebreaker & $\begin{array}{l}\text { Introduce the project and goals of } \\
\text { group dynamics; introduction to } \\
\text { the dairy sector in the region; } \\
\text { introduction of individual } \\
\text { participants }\end{array}$ & $\begin{array}{l}13 \text { participants, } 1 \text { moderator, } 1 \\
\text { project coordinator }\end{array}$ & 30 \\
\hline 2-SWOT analysis & $\begin{array}{l}\text { A few moments for individual } \\
\text { reflection; identification of factors } \\
\text { and ensuing discussion }\end{array}$ & $\begin{array}{c}13 \text { participants, } 1 \text { moderator, } 1 \\
\text { facilitator (notes on board), } 1 \\
\text { facilitator (photos and notetaking), } \\
1 \text { facilitator (notetaking) }\end{array}$ & 55 \\
\hline $\begin{array}{l}\text { 3-Identification of main areas of } \\
\text { interest (needs) }\end{array}$ & $\begin{array}{l}\text { The main areas of interest were } \\
\text { identified based on the SWOT } \\
\text { analysis, and their importance } \\
\text { was assessed by the participants }\end{array}$ & $\begin{array}{l}13 \text { participants, } 1 \text { moderator, } 1 \\
\text { facilitator (notes on board), } 1 \\
\text { facilitator (photos, distribute } \\
\text { stickers and notetaking), } 1 \\
\text { facilitator (notetaking) }\end{array}$ & 35 \\
\hline Break & $\begin{array}{l}\text { Coffee break in the vestibule of } \\
\text { IBADER }\end{array}$ & $\begin{array}{l}13 \text { participants, } 1 \text { moderator, } 3 \\
\text { facilitators, } 1 \text { project coordinator }\end{array}$ & 30 \\
\hline $\begin{array}{l}\text { 4-Identification of services and } \\
\text { dysservices }\end{array}$ & $\begin{array}{l}\text { Prepare a list organized by type of } \\
\text { service/dysservice. Discussion, } \\
\text { explanations and improvement }\end{array}$ & $\begin{array}{l}13 \text { participants, } 3 \text { facilitators, } 1 \\
\text { moderator. During discussion: } 1 \\
\text { moderator, } 3 \text { facilitators } \\
\text { (notetaking, photos). }\end{array}$ & 75 \\
\hline 5-List of innovative practices & $\begin{array}{c}\text { Individual reflection. Share ideas } \\
\text { with the group, and subsequent } \\
\text { analysis of relevant factors and } \\
\text { farms }\end{array}$ & $\begin{array}{l}13 \text { participants, } 1 \text { moderator, } 1 \\
\text { facilitator (notetaking), } 1 \\
\text { facilitator (photos, notetaking), } 1 \\
\text { facilitator (notetaking) }\end{array}$ & 45 \\
\hline
\end{tabular}

The third segment of the group session ( $35 \mathrm{~min}$ ) focused on identifying the main areas of interest for dairy production models in the region. The SWOT analysis was used to 
identify the main areas of interest (20 min); these ideas were then pooled and classified by subject (economy, society, environment and agriculture) on another whiteboard. The participants then rated the ideas in order of importance (15 min).

The fourth segment $(75 \mathrm{~min}$ ) focused on creating a list of services and dysservices related to the identified subject areas. Unlike other studies, participants were not provided with a list of services and dysservices prior to the discussion [29,36]. For the first $45 \mathrm{~min}$, the 13 participants were separated into breakout groups according to the four previously defined agroecosystem service categories (provisioning services, rural vitality, environment, and cultural heritage and quality of life). Each group worked with a facilitator, whose role was to respond to questions, explain concepts, and facilitate effective communication and understanding. Each group was tasked with preparing an organized list by subject area (economy, society, environment and agriculture), in order of relevance, and describing the services and dysservices and specific production models associated with these services and dysservices. Two types of production models were considered: Intensive systems and Extensive/Organic systems. In the remaining $30 \mathrm{~min}$, a representative selected by the members of each breakout group presented the results of their group, which were listed on the whiteboard, discussed and refined.

During the fifth segment $(45 \mathrm{~min})$, participants were asked what practices they would implement to promote the services and limit the dysservices on the list. After five minutes of reflection, group ideas were listed on a second whiteboard for analysis by all participants. The results of the FG are not presented here, as the group responded primarily with a list of ideas for avoiding threats and weaknesses and exploiting strengths and opportunities, which more closely resembled a reflection on the SWOT analysis.

\section{Results}

This article focuses on the results obtained during the fourth segment of the FG regarding the main services and dysservices. We were able to identify 27 agroecosystem services, which we have classified according to the categories established by Ryschawy et al. [11] (Figure 2).
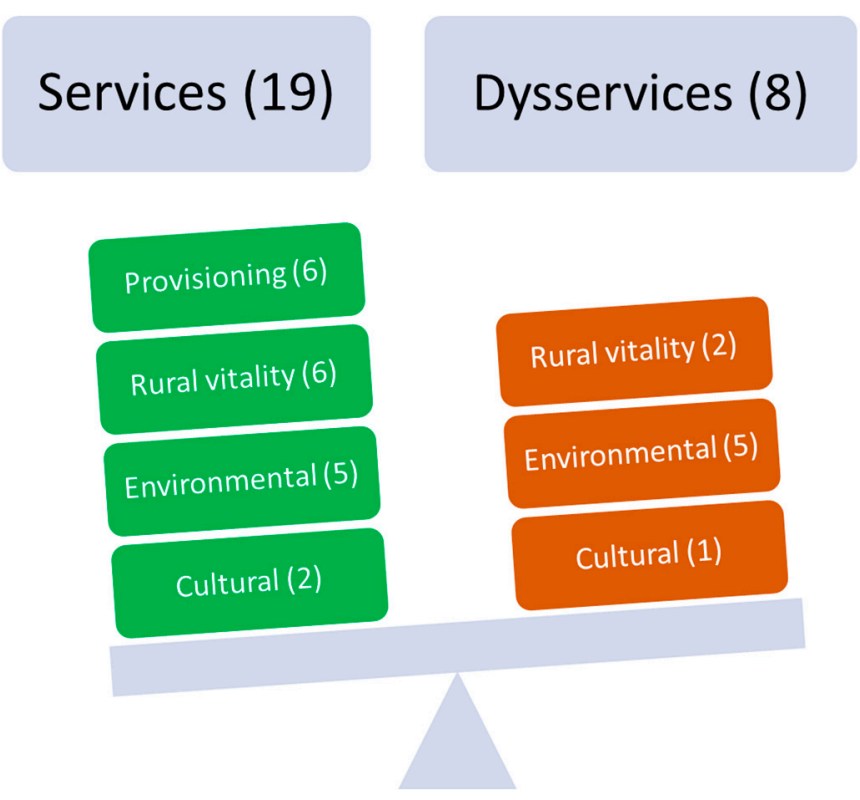

Figure 2. Number of services and dysservices identified by category.

The first finding we wish to highlight is an imbalance between the number of services and dysservices identified: 19 services, compared to 8 dysservices. The area with the greatest lack of consensus was environment where ten elements were identified as dysservices or services, but participants only arrived at a consensus on six. 
For each of the four categories, participants were asked to identify in the clearest terms possible the production model associated with the service or dysservice. Few of the participants were familiar with the concept of agroecosystem services. Although FG facilitators explained in detail what they wished to identify, the discussion revolved predominantly around different topics that were important for the sector, but which did not constitute services or dysservices. We have included only those elements corresponding to concepts we wished to analyze. Additionally, participant views expressed during the fourth segment of the FG session revolved primarily around animal husbandry, to the exclusion of other elements of the value chain. The primary findings are explained below, organized according to the four categories defined in the methodology.

\subsection{Provisioning Services}

Six services and no dysservices were identified in this category. As shown in Figure 3, for four of the six provisioning services participants consider that they are supplied regardless of the production model. They are included here the direct sale of dairy products processed on the farm (pasteurized milk, cheeses, yogurt), and other products derived from livestock farming, such as meat (fattened calves or cull cows), crop production, and heifers and steers.

\section{PROVISIONING SERVICES}

Conventional milk production

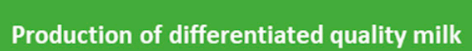

Meat production

Direct supply of processed dairy products

Fooder production

Heifers for rearing

Figure 3. Identified provisioning services.

The service of conventional dairy production was related to intensive production models, and participants highlighted the importance of these systems as a means to satisfy a growing international demand for this product. Finally, was pointed out the supply of products carrying a food quality label. The most commonly mentioned certifications were organic production, grass-fed dairy and animal welfare. Participants linked this service to extensive farming practices and organic certification schemes.

\subsection{Rural Vitality}

Six services and two dysservices were identified in this category (Figure 4). The services are primarily related to employment and income generation, with two different types: 
- Those related to employment in rural areas. In addition to direct jobs on dairy farms, participants also highlighted the positive impact of employment opportunities throughout the value chain, including the rural processing industry and input suppliers to farms.

- Income generation, which helps to support the local economy. Another service identified for livestock regions is the capacity of this activity to support a network of businesses linked to the local economy.

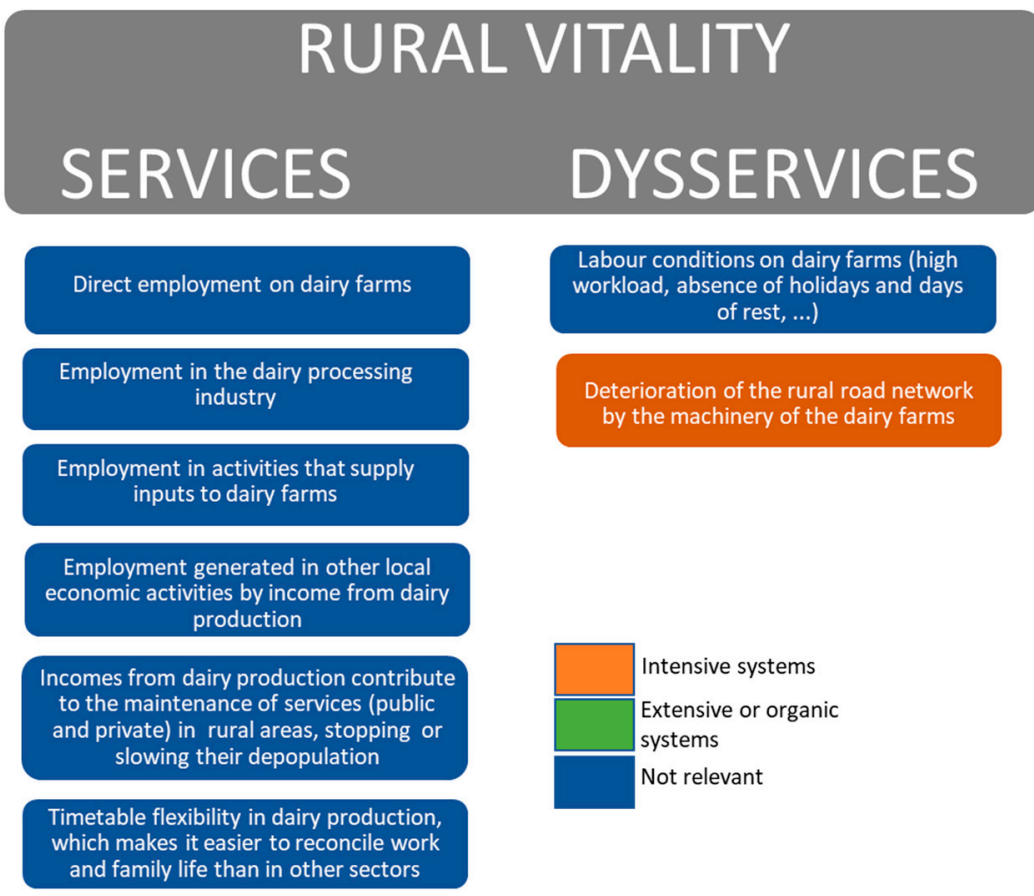

Figure 4. Identified rural vitality services and dysservices.

Of particular interest is the inclusion of a fifth service related to the maintenance of public and private services in rural areas through the income generated by the sector, which is crucial to supporting rural population. This element is among those that generated the highest level of consensus during the discussion. The final service is related to quality of life and work-life balance. Participants mentioned the flexible timetable associated with dairy production as compared to other types of employment or activities, making it easier to balance work and family.

Two dysservices were mentioned in the category of rural vitality: working conditions (related to longer working hours, and no holidays or days off), and the wear and tear on rural road networks from farm machinery. This is the only element on the list of services and dysservices that was associated with a specific production model, i.e., intensive systems.

\subsection{Environment}

Five services and five dysservices were linked to dairy production in the category of environmental conservation and biodiversity (environmental quality) (Figure 5). It is interesting to note that this was the only established category for which there was a lack of consensus in attributing the related services and dysservices to one production model or another (intensive, extensive, both). The composition of the breakout group explains this lack of consensus, with some representatives more closely linked to intensive production models, and others related to extensive farming practices or environmental organizations. 


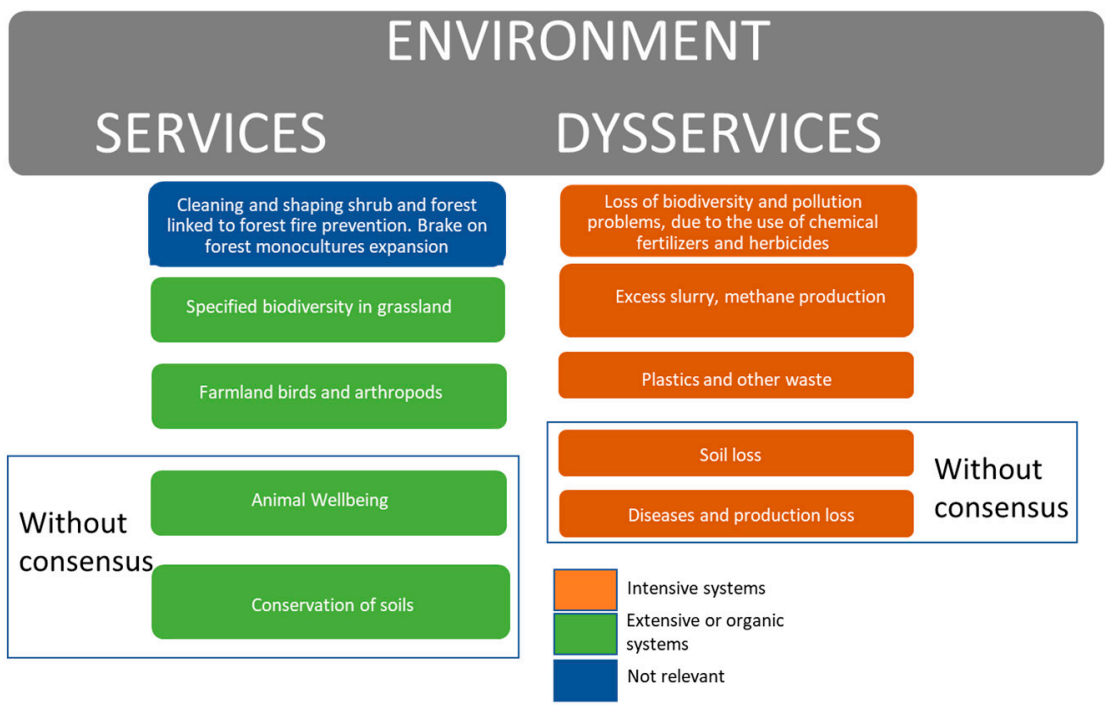

Figure 5. Identified environment services and dysservices.

The first environmental service identified by the participants, relating to both extensive and intensive systems, is the importance of grasslands and cropland in the prevention of wildfires, either because they act as a firebreak, or because livestock helps to control the amount of biomass, therefore controlling the burnable fuel and reducing the fire hazard. A second service is related to the specific biodiversity of natural grasslands, which are associated with extensive and organic systems. The habitat that grasslands provide for birds and arthropods was identified as a third environmental service and is again associated with less-intensive production models.

Two further services were identified, although no consensus was reached. The first is related to soil conservation, which some of the participants associate solely with the grazing from organic farming techniques, with the explanation that well-managed pastures provide permanent plant coverage to prevent erosion, and that the livestock contributes organic matter to the soil, providing nutrients and stability. The second service without consensus relates to the capacity of breeding and welfare conditions to extend the life of the animals. Here again, a portion of participants associate this service exclusively with extensive and organic farming systems, while other participants also associate it with intensive systems, asserting full compliance with current legislation.

In the area of environmental dysservices, the first was biodiversity loss and soil contamination as a result of the use of chemical fertilizers and herbicides. Closely related is the dysservice related to plastic and other waste generated by the livestock sector, with a third one related to an excess of liquid manure and methane production, all associated with intensive production models.

Dysservices identified by one of the participants, but without consensus, are both associated with intensive systems: soil loss as a result of the continuous extraction of nutrients in intensive systems, and the spread of disease.

\subsection{Cultural Heritage and Quality of Life}

Only two services and one dysservice were identified for this category (Figure 6). The participants identified the following two services:

- Safeguarding of cultural heritage and traditions. The participants defined this service as the role that dairy farming plays in consolidating the rural population, ensuring that this contributes to preserving cultural traditions and historical heritage (related in part to farms). Included in the sub-service of preserving cultural traditions, reference was made to the terminology associated with agricultural and livestock activity, work implements and techniques, and the production of native plant varieties and animal 
breeds. Participants considered that this activity contributes to the transmission of skills and knowledge from generation to generation by consolidating the rural population.

- Landscape preservation. This service generated a great deal of heated debate related to the fact of whether landscape preservation could be linked with intensive production models, as well as with extensive and organic practices. Finally, the participants agreed in their perspective on landscape, which was closely linked to modern agricultural practices.

\section{CULTURAL HERITAGE AND QUALITY OF LIFE SERVICES DYSSERVICES}

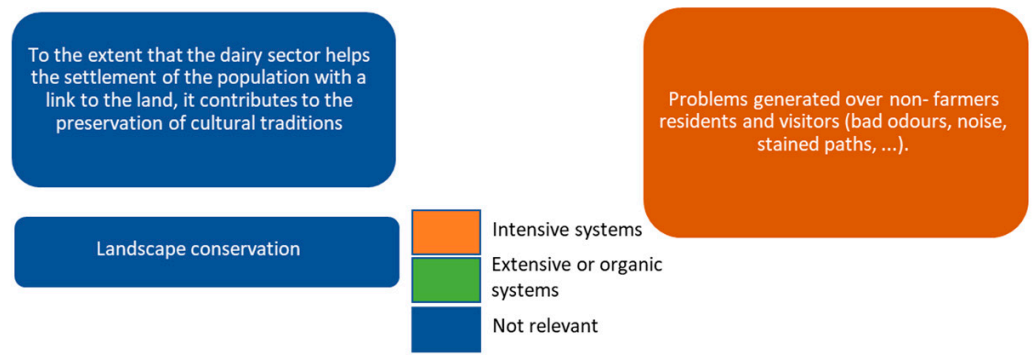

Figure 6. Identified cultural heritage and quality of life services and dysservices.

The only negative impact identified in this category were the problems generated by intensive production models for visitors and for local residents not associated with the dairy farming sector, such as foul smells, noise, road wear and tear.

\section{Discussion}

\subsection{Focus Group Perception}

Our aim was to better understand the impact of dairy farming on economic welfare, employment, rural vitality and the environment in Galicia by identifying the agroecosystem services and dysservices it provides. It is important to identify the perception of both agroecosystem services and dysservices generated by the dairy sector in order to react to society's changing requirements and demands regarding dairy products, and of the role that dairy farming plays in the territory and the environment. At the same time, knowledge of services and dysservices rendered allows for better compensation of these activities, not only in the light of their marketable expressions, but also considering all other services and the roles these ecosystems play in the territory and in society $[29,36]$.

Unlike other studies aimed at identifying agroecosystem services derived from dairy production, which opted for focus groups divided by type of participant $[29,30,36]$, the focus group approach we used aimed to reflect the diversity of actors present throughout the value chain. The heterogeneous make-up of the breakout groups partially accounts for the lack of consensus on several of the issues under discussion, particularly as regards environmental services and dysservices, but it paints a more representative portrait of the opinions present in the sector. As Ripoll-Bosch et al. [54] has stated, sustainability is a complex and dynamic concept that involves dimensions dependent on the context. In this sense, an integrated sustainability assessment of agroecosystems should follow a participative approach to understand the multiple views and relationships (trade-offs or synergies) between dimensions and stakeholders' priorities [54]. The FG method allows to tackle theses multiple relationships. For instance, Bernués et al. [36] also find differences among focus groups regarding the same type of agroecosystem services. For example, farmers and non-farmers diverge in discussions of the relationships between farming and the conservation of endangered species, with non-farmers being more amenable to 
conservation. In our case, members of conservation organizations and members related to organic and extensive production were more aware of conservation concerns, recognizing the dysservices rendered by intensive systems and the regulation services rendered by extensive systems. This heterogeneous composition also accounted for the differences in results obtained by Swagemakers et al. [25] for the same geographical area. This last study focused solely on the opinion of livestock farmers but with representatives from both of the production models considered in our work.

Poor understanding of the concept of agroecosystem services was reported by Bernués et al. [36], who attempted to minimize these problems of understanding by selecting a focus group of non-farmers with an intermediate level of formal education. Montrasio et al. [29] used an online interview technique and found that the perception of agroecosystem services was statistically lower for respondents with a low educational level. More responses were provided from non-farmers, which may illustrate a lack of understanding of the concept among the group dairy producers.

One of the most surprising points of our study is the imbalance between the number of services and dysservices that were identified. This is partially due to the fact that while the concept of services and dysservices was generally unfamiliar to participants, there was greater awareness of the concept of ecosystem services, for which extensive literature is available, than of dysservices [20,23], for which a thorough definition is nonexistent. Notwithstanding, as Shackelton et al. [23] have stated, "investments into the management or reduction of ecosystem dysservices may yield better outcomes for human well-being." This is particularly relevant in a sector such as dairy production, which has been associated with numerous negative effects, in particular for the environment and by intensive production models $[1,31,55,56]$. To counterbalance this weakness, the facilitators throughout the discussions, denominated services and dysservices as positive and negative effects of the dairy sector on society.

We can also justify the greater number of services as compared to dysservices by considering the social and economic significance of dairy production in Galicia. This significance explains the positive viewpoint expressed by participants in relation to the activity with which they are involved. This positive outlook is also reflected in the strengths that were identified during the sector SWOT analysis sessions: the professional vocation of the sector, good training, and a strong capacity to adapt explained the larger number of services identified, particularly for the provisioning and rural vitality categories. Ryschawy et al. [11] finds that services related to these two categories correlate positively with their analysis of the provisioning of livestock goods and services in France. Villar et al. $[57,58]$ identify certain provisioning services, such as grass-fed milk or direct sales of pasteurized milk on the farm, also identified in our breakout group, and others linked to value creation, enhanced economic activity, generation of employment, and the contribution to regional market appeal for tourists. Broadly speaking, the conclusion that emerged from the discussions in our focus group was that the greater number of goods and services provided by the sector should be reflected in a higher employment rate and stronger economic dynamics in the region. This relation between provisioning and rural vitality services is illustrated by the fact that the group highlighted "the strengthening of corporate structures, including the participation of farmers in industrial dairy processing schemes" as an opportunity for the future of the sector.

We should consider whether the sector, as represented in our focus group, identifies the same categories of services and dysservices for itself as those found in the literature, and whether there is awareness of the contribution of the sector to society, both in positive and negative terms, beyond the mere provisioning of goods and services. In this sense, the category related to cultural heritage and quality of life services is where we see the greatest number of gaps, and the environmental category shows the greatest divergence of opinion.

An added difficulty emerges when we associate services and dysservices with a specific production model. For the majority of categories there is no clear assignation of items to a specific model. The exception is the environmental impact category, where services 
tend to be associated with extensive models, and dysservices with intensive systems. This is reflected by the fact that more studies have been conducted on environmental services provided by extensive systems. The majority of studies on the agroecosystem services provided by the livestock sector have targeted grazing, pasture-based and mountain livestock systems $[26,29,36]$, and the identified services have been predominantly environmentrelated [26,31]. The impact of dysservices is less predominant in these models [29].

\subsection{Services}

In Provisioning Services, the core service identified is milk production, which this breakout group classified into two types according to the production model: conventional milk production linked to intensive systems and related to the provision of an increasing demand for milk and dairy products [59]; and production of milk carrying a food quality certification, produced by extensive systems and linked to organic labeling, grazing and animal welfare. Different studies identify quality production as an agroecosystem service provided by extensive systems, associating quality with good nutrition and ethical production practices $[11,36,57]$. Changes have been registered in European consumption habits in recent years, with a lower liquid milk intake and increased concern with health, quality products, and food safety $[58,60,61]$.

Missing from this list is the provisioning of natural fertilizers, identified by inhabitants of the Italian Alps as a service provided by mountain livestock systems [29], and which indicates a more organic model.

As indicated above, the Rural Vitality element has been largely ignored in existing literature [11], including those aspects affecting the social sustainability of livestock models [31]. This category was well recognized by the breakout group in Galicia, however, and they identified services associated with the generation of work and maintenance of services in the region. Similar to the studies by Ryschawy et al. [11] and Beudou et al. [62] for different regions in France, the breakout group distinguished between employment generated directly by livestock farming (on farms) and indirectly (via input suppliers and supply chains, as well as in support services). Actors in the two territories emphasized the importance of livestock farming for rural life, in that it maintains shops, public and private services, and associations on the territories and social life. Bernués et al. [36] find that the quality of life and working conditions are two elements that agricultural workers consider to be essential to their social sustainability.

For Galicia, the emphasis on employment generated by the sector is visible in employment data available from recent years. While the dairy farming sector per se generates only a modest amount of employment in global terms, the clear concentration of the sector in the region makes its impact even more relevant [63]. Additionally, an increase in the economic size of holdings has led to the creation of a relatively new phenomenon in Galician agriculture: salaried employment. In 2016, salaried labor in livestock farming already accounted for $33.2 \%$ of total AWUs for holdings specialized in dairy cow milk production in Galicia [42]. This phenomenon is on the rise, and recent years have seen an increase in the scale of production for bovine livestock holdings, accompanied by a greater relevance of types of business organization and salaried employment [64]. If we consider the employment created by the dairy industry, while the generation of employment by the processing industry was identified as a service, the group is aware that this capacity is limited. During the SWOT analysis of the sector, one of the economic weaknesses that was identified was the "low added value of the dairy industry in Galicia, given the specialization in packaged milk production." This vision does indeed mirror reality, as processing capacity is low (52\% of milk produced in 2018), and the majority of the milk processed in Galicia is milk for human consumption, with a strong emphasis on private labels [65].

Interestingly, the breakout group identified working conditions in the sector both as a service and a dysservice. The flexible timetable was considered a service, as it permits a greater work-life balance and contributes to the quality of life, while the lack of vacation 
time and the strenuousness of the work were considered dysservices, in that the work does not attract young people.

The services and dysservices identified for the rural vitality category were identified for both production models in Galicia. This point stands in contrast to the sector studies in France. Beudou et al. [62] found that rural vitality services are linked to the current industrialized livestock model, whereas cultural services were more linked to the pre-1970s traditional production model in France.

The breakout group in Galicia associated services related to the Cultural Heritage and Quality of Life element with both production models, including the preservation of traditions in that the sector consolidates the population in rural areas, and the population in turn preserves cultural traditions. Landscape preservation was another element that was mentioned. It was clear throughout the discussion that breakout group members considered that a traditional landscape was a completely modified landscape, but it was perceived as the landscape they have always known; this service was therefore not associated exclusively with extensive models. In contrast, Rischawy et al. [11] and Beudou et al. [62] find that synergies between the rural vitality and the cultural heritage and quality of life categories in extensive models in particular, contribute to the preservation of traditional landscape elements. In their study on the sector in the Italian Alps, Montrasio et al. [29] identify landscape preservation by mountain livestock models as one of the most highly regarded agroecosystem services for participants in the study. Here as well, services related to rural vitality and cultural heritage and quality of life are interrelated through tourism. Bernués et al. [36] find that recreation and tourism are connected with landscape aesthetics provided by agricultural models with high natural value. Finally, the study conducted by Swagemakers et al. [25] reveals that for Galicia, it was the organic dairy producers and the diversified conventional dairy farmers who most clearly expressed their interrelations with the natural environment, combining productive farm activities with locally marketing food products and agro-tourism activities. They provide the most detailed description of the benefits derived from traditional landscape elements, traditional houses and buildings, stone walls, and hedgerows. Notwithstanding, this practice has only a token presence in the region of Galicia; in 2016, only 5 holdings classified as TF specialist dairy out of a total of 8462 provided complementary activities such as agro-tourism, accommodation, and recreational options (INE, 2016) [42].

Our study is consistent with another of the correlations found by Ryschawy et al. [11]: environmental and cultural categories are negatively correlated with the provisioning category. Less productive systems, i.e., extensive models, are more closely linked to the provision of environmental services. As indicated above, available literature offers us an extensive catalog of environmental agroecosystem services provided by pastured livestock systems, and those identified by our focus group are the most common: biodiversity conservation, genetic pool conservation, animal welfare or conservation of soils from erosion. Cooper et al. [66] associate low-impact grazing models with a higher degree of biodiversity; Swagemakers et al. [25] found that the same services were identified by Galician farmers, which they associated with extensive livestock models. The studies of Valladares et al. [67], also conducted in Galicia, point to restricted biological wealth for intensive models, where single crops and repeated annual crop rotation (corn-ryegrass) are the norm.

We would like to underline the effect of grazing on the prevention of wildfires through cleaning and shaping shrubs and forest, as well as the role it plays in curbing the expansion of forest monocultures. The latter service, identified for both intensive and extensive systems, is associated with the maintenance of pastures and cultures in a typical mosaic landscape. This recurrent issue is reported in several works $[29,36]$ as disturbance prevention, always associated with extensive livestock models. The breakout group reached a consensus on this point only after an intense debate regarding which productive model performs better in this sense, illustrating both the significance of wildfires as one of the major environmental problems in Galicia and the controversy they generate. Several au- 
thors have pointed out that the expansion of wildfires here is due to the abandonment of agricultural land as a result of the structural adjustment process of recent decades $[4,68]$.

Animal welfare and soil conservation are other environmental services for which a consensus was not reached. The level of divergence regarding this service reflects the different outlooks of group members if we consider the different arguments that support each of the production models. It is clear that the overexploitation of resources (excess livestock density) and bad practice (grazing in wetlands) can eventually lead to desertification and soil compaction in grazing systems [36]. The agroecosystem services provided by livestock models therefore depend to a great extent on the resource management and practices used by farmers [25]. The discussion on animal welfare in intensive models points to what Bernués et al. [36] and Van Oudenhoven et al. [69] highlight when they state that the benefits depend on the perception of value held by different social actors.

Finally, we will point out that the focus group did not identify environmental services that are frequently mentioned for animal production systems. One of these is the filtration and regulation of water flow associated with extensive agroecosystems, through the effectiveness of grasslands in filtering runoff $[26,27,29,36]$. This service was, however, perceived for forest systems in the same area of study [70]. Other services that were not mentioned were waste management, pest control and pollination [27,29], not even for extensive models. Finally, it is striking that the group did not identify the service of carbon capture and sequestration provided by grasslands and pastures [46], which is particularly relevant in a sector that is currently being criticized for the emissions it generates.

\subsection{Dysservices}

Agroecosystems, which are modeled by human activity, can render both services and dysservices depending on the intensity of pressures done. For instance, livestock grazing systems can contribute to carbon capture and sequestration, but an intensive management of these systems would release carbon rather than capturing it, as a result of overgrazing or increased livestock density. It is because the production system is an important feature to analyse together with the services or dysservices identified.

We have already pointed out that few dysservices were identified overall, and that those that were mentioned were environment-related [29] and primarily associated with intensive production models, which is in line with the findings of other studies [29,71]. Three dysservices were identified by the provisioning services breakout group (an excess of liquid manure, waste management (plastics) and pollution), which we decided to include in the environmental impact group. Biodiversity loss and pollution associated with dairy production are elements that have also been reflected in various studies, including Wiesner et al. [72], who consider that an intensification of agricultural practices, particularly in relation to dairy production, has led to an increase in emissions as a result of unsustainable practices. Improper management of liquid manure (low-capacity tanks, reduced land area, improper application ) creates a range of environmental impacts, such as foul odors, greenhouse gases in the form of nitrous oxide, and eutrophication. Salcedo [46] analyzes greenhouse gas emissions for several foraging models and finds that more intensive foraging results in increased emissions, but grassland carbon sequestration can compensate this increase. Surprisingly, this service was not identified by our group.

Moving to the second dysservice, the main problem with plastic waste is the lengthy biodegradation process and high level of pollution it generates [73]. In Galicia, there is an abundance of silage plastic: 7700 tons per year [74]. The increasing concentration of livestock production activity in certain areas of the region in the 1990s, together with the generalized use of a highly industrialized production model, exacerbates the impact of this plastic waste as it builds up in uncontrolled landfills in the areas mentioned, despite the practice of reusing these materials on holdings. Foul odors were identified as a dysservice in the cultural heritage and quality of life category, as they are unpleasant for non-farmers and visitors to the region. 
One difference in this study is the identification of dysservices in the rural vitality category. Typically absent in the literature, we had to consult other types of studies that analyze different production systems, such as forest models, to find the dysservices mentioned by our focus group [70]. One example is the contribution of farm machinery to the deterioration of the rural road network. This dysservice is associated with intensive production models and has emerged as a result of recent agricultural evolution in more highly developed countries, characterized by a greater degree of mechanization [75], and modernization of machinery prompted by technological development [76]. Other factors associated with this dysservice are the individualization of work of farm owners [77], the outsourcing of jobs to service companies, and the pressure exerted by commercial suppliers [78].

The second dysservice identified by the group-working conditions on dairy farmsis also lacking in the literature on services and dysservices. The rural vitality category included working conditions in the dairy sector to give visibility to the contribution of the sector to the creation of employment in rural areas. It was inevitable that working conditions should be the focus of this debate. We have thus decided to include the comments of participants regarding poor working conditions as a dysservice in this category. They maintain that such conditions drive young people away from this activity, thereby contributing to the emigration of young people from rural areas. The emigration of young people is closely related to the lack of employment opportunities beyond the primary sector in rural areas, which is left behind as these young people achieve higher levels of education [79]. This situation is manifested in Galicia through phenomena such as a lower proportion of Galician dairy farms that are passed on from parent to child [45], linked to the inability of the rural Galician sector to create new employment opportunities $[4,63]$.

Soil loss and diseases and production loss were mentioned without consensus by a few members of the breakout group. Both dysservices are a result of the trade-offs mentioned by Zabala et al. [27] and illustrated by Rischawy et al. [11] through a positive correlation between provisioning services and rural vitality, and a negative correlation with environmental services. The greater intensification of holdings with a view to increasing production and profits may lead to an increase in diseases, and ultimately, to problems producing milk and forage. In connection with this, Rodríguez-Bermúdez et al. [80] state that organic farm owners prefer breeds and handling procedures that guarantee fewer medical issues, higher fertility rates, and greater longevity of animals, even at the expense of a lower output per animal.

It is interesting to point out the absence of provisioning dysservices that have been identified in other studies, such as competition for water with other ecosystems [20,27,81], which may be ignored in an area with abundant rainfall; or lower food quality [29]. The last dysservice was not specified in the discussion about dysservices but was brought up during the final session when the group proposed, as an important action for the sector, to improve the quality of dairy products.

As described in the methodological section, the discussion on ecosystem services was preceded by two other dynamics: one on the strengths and weaknesses of the sector and the other on the needs perceived by stakeholders. The results of these dynamics are not the object of this paper, but Vázquez-González et al. [82] summarizes the main results. Stakeholders pointed out that environmental sustainability as one of the weaknesses of the dairy sector, which is consistent with the large number of environmental dysservices identified. Thus, making society aware of the multiplicity of agroecosystem services rendered by the dairy sector was one of the needs detected among others, as well as the need to move towards the sustainability of the value chain through the development of high-quality products with more value added. On the other hand, and being coherent with these results, the practices to be promoted by the sector itself or by the administration would be to make agroecosystem services more visible, especially those less identified, such as rural vitality and cultural services. Moreover, the sector is aware of the environmental impact of its activity, which makes it more feasible to adopt measures to limit the number 
and type of dysservices, for instance, the adoption of quality seals or the practice of pasturebased feeding. These behaviors fit well with the main issues drawn by the European Green Deal or the A Farm to Fork Strategy [83]. The analysis also shows the need to make the stakeholders aware of the environmental dysservices not identified by them in Galicia.

\section{Conclusions}

Our study provides insight into the perception of dairy sector actors regarding the positive and negative impacts of the activity on society beyond marketable goods and services. It constitutes the first step towards identifying practices and policies that could enhance services and reduce dysservices. The sector offers a positive vision of itself, reflecting the economic and social importance of the dairy sector in Galicia.

The participants exhibit good awareness of different services and dysservices, particularly rural vitality and environmental services. Notwithstanding, we encountered some important gaps regarding services rendered, such as the carbon sequestration capacity of pastures, and difficulties recognizing some dysservices, evidenced by the absence of consensus on several points.

One of the innovative findings regarding the social role of farming in this area is the identification of rural vitality services and dysservices for maintaining and consolidating population in rural areas, as well as preserving traditions and culture.

Extensive and organic systems are perceived as those which make the greatest contribution to the delivery of environmental services, while the majority of dysservices are associated with intensive systems. The contribution to rural vitality is considered to be delivered by both production models.

Author Contributions: Conceptualization, E.L.-I. and A.I.G.-A.; methodology, I.V.-G., B.V.-P. and M.d.M.P.-F.; acquired and validation data I.V.-G., B.V.-P., A.I.G.-A. and M.d.M.P.-F.; original draft preparation I.V.-G., A.I.G.-A. and M.d.M.P.-F.; writing-review and editing, all authors contributed to writing of this manuscript; project administration, E.L.-I. All authors have read and agreed to the published version of the manuscript.

Funding: This research has received funding from the "Dairy-4-Future" project of the Interreg Atlantic Area Program (EAPA_304/2016) and from the Program for the "Consolidation and Structuring of Competitive Research Units-Competitive Reference Groups" (Ref. ED431C 2020/13) of the Xunta de Galicia (Spain).

Institutional Review Board Statement: Not applicable.

Informed Consent Statement: Not applicable.

Data Availability Statement: Not applicable.

Conflicts of Interest: The authors declare no conflict of interest.

\section{References}

1. Kraham, S.J. Environmental impacts of industrial livestock production. In International Farm Animal, Wildlife and Food Safety Law; Steier, G., Patel, K., Eds.; Springer: Cham, Switzerland, 2017; pp. 3-40. [CrossRef]

2. Redclift, M. Sustainable Development: Exploring the Contradictions; Routledge: London, UK, 1987.

3. Sineiro-García, F.; Lorenzana-Fernández, R.; Vázquez-González, I. Current situation and expected changes in the structure and productive system of Galician dairy farms. Pastos 2012, 42, 67-92.

4. López-Iglesias, E.; Sineiro-García, F.; Lorenzana-Fernández, R. Processes of Farmland Abandonment: Land use Change and Structural Adjustment in Galicia (Spain). In Agriculture in Mediterranean Europe: Between Old and New Paradigms; Ortiz-Miranda, D., Moragues-Faus, A., Arnalte-Alegre, E., Eds.; Emerald Group Publishing Limited: Bingley, UK, 2013; pp. 91-120.

5. Calvo-Iglesias, M.S.; Crecente-Maseda, R.; Fra-Paleo, U. Exploring farmer's knowledge as a source of information on past and present cultural landscapes: A case study from NW Spain. Landsc. Urban Plan. 2006, 78, 334-343. [CrossRef]

6. Swagemakers, P.; García, M.D.D.; Fernández, X.S.; Wiskerke, J.S. Unfolding farm practices: Working toward sustainable food production in the Netherlands and Spain. J. Agric. Food Syst. Community Dev. 2012, 2, 129-145. [CrossRef]

7. Altieri, M.A. Agroecology: A new research and development paradigm for world agriculture. Agric. Ecosyst. Environ. 1989, 27, 37-46. [CrossRef] 
8. Sevilla Guzmán, E.; Martínez Alier, J. New rural social movements and agroecology. In Handbook of Rural Studies; Cloke, P., Marsden., T., Mooney, P.H., Eds.; Sage: London, UK, 2006; pp. 472-483.

9. van der Ploeg, J.D. The New Peasantries: Struggles for Autonomy and Sustainability in an Era of Empire and Globalization; Earthscan: London, UK, 2008; pp. 1-363.

10. Toledo, V.M. The ecological rationality of peasant production. In Agroecology and Small Farm Development; Altieri, M.A., Hecht, S.B., Eds.; CRC Press: Boca Raton, FL, USA, 1990; pp. 53-60.

11. Ryschawy, J.; Disenhaus, C.; Bertrand, S.; Allaire, G.; Aznar, O.; Plantureux, S. Assessing multiple goods and services derived from livestock farming on a nation-wide gradient. Animal 2017, 11, 1861-1872. [CrossRef]

12. Costanza, R.; Daly, H.E. Natural capital and sustainable development. Conserv. Biol. 1992, 6, 37-46. [CrossRef]

13. Costanza, R.; d'Arge, R.; De Groot, R.; Farber, S.; Grasso, M.; Hannon, B. The value of the world's ecosystem services and natural capital. Nature 1997, 387, 253-260. [CrossRef]

14. Daily, G.C. Nature's Services: Societal Dependence on Natural Ecosystems; Island Press: Washington, DC, USA, 1997 ; p. 392.

15. Westman, W.E. How much are nature's services worth? Science 1977, 197, 960. [CrossRef]

16. De Groot, R.S.; Alkemade, R.; Braat, L.; Hein, L.; Willemen, L. Challenges in integrating the concept of ecosystem services and values in landscape planning, management and decision making. Ecol. Complex. 2010, 7, 260-272. [CrossRef]

17. Assessment, M.E. Ecosystems and Human Well-Being; Island Press: Washington, DC, USA, 2005; Volume 5, p. 563.

18. Sukhdev, P.; Wittmer, H.; Schröter-Schlaack, C.; Nesshöver, C.; Bishop, J.; Brink, P.T.; Simmons, B. The Economics of Ecosystems and Biodiversity: Mainstreaming the Economics of Nature: A Synthesis of the Approach, Conclusions and Recommendations of TEEB; UNEP: Ginebra, Switzerland, 2010.

19. Haines-Young, R.; Potschin, M.B. Common International Classification of Ecosystem Services (CICES) V5.1 and Guidance on the Application of the Revised Structure; Centre for Environmental Management, University of Nottingham: Nottingham, UK, 2018; Available online: http:/ / www.cices.eu/ (accessed on 8 July 2021).

20. Zhang, W.; Ricketts, T.H.; Kremen, C.; Carney, K.; Swinton, S.M. Ecosystem services and dis-services to agriculture. Ecol. Econ. 2007, 64, 253-260. [CrossRef]

21. Dunn, R.R. Global mapping of ecosystem disservices: The unspoken reality that nature sometimes kills us. Biotropica 2010, 42, 555-557. [CrossRef]

22. Escobedo, F.J.; Kroeger, T.; Wagner, J.E. Urban forests and pollution mitigation: Analyzing ecosystem services and disservices. Environ. Pollut. 2011, 159, 2078-2087. [CrossRef]

23. Shackleton, C.M.; Ruwanza, S.; Sanni, G.S.; Bennett, S.; De Lacy, P.; Modipa, R. Unpacking Pandora's box: Understanding and categorising ecosystem disservices for environmental management and human wellbeing. Ecosystems 2016, 19, 587-600. [CrossRef]

24. Norgaard, R.B. Ecosystem services: From eye-opening metaphor to complexity blinder. Ecol. Econ. 2010, 69, 1219-1227. [CrossRef]

25. Swagemakers, P.; Dominguez Garcia, M.D.; Onofa Torres, A.; Oostindie, H.; Groot, J.C. A values-based approach to exploring synergies between livestock farming and landscape conservation in Galicia (Spain). Sustainability 2017, 9, 1987. [CrossRef]

26. Rodríguez-Ortega, T.; Oteros-Rozas, E.; Ripoll-Bosch, R.; Tichit, M.; Martín-López, B.; Bernuès, A. Applying the ecosystem services framework to pasture-based livestock farming systems in Europe. Animal 2014, 8, 1361-1372. [CrossRef]

27. Zabala, J.A.; Martínez-Paz, J.M.; Alcon, F. A comprehensive approach for agroecosystem services and disservices valuation. Sci. Total Environ. 2021, 768, 144859. [CrossRef]

28. Dolman, M.; Sonneveld, M.; Mollenhorst, H.; De Boer, I. Benchmarking the economic, environmental and societal performance of Dutch dairy farms aiming at internal recycling of nutrients. J. Clean. Prod. 2014, 73, 245-252. [CrossRef]

29. Montrasio, R.; Mattiello, S.; Zucaro, M.; Genovese, D.; Battaglini, L. The Perception of Ecosystem Services of Mountain Farming and of a Local Cheese: An Analysis for the Touristic Valorization of an Inner Alpine Area. Sustainability 2020, 12, 8017. [CrossRef]

30. van den Pol-van Dasselaar, A.; Hennessy, D.; Isselstein, J. Grazing of dairy cows in Europe-An in-depth analysis based on the perception of grassland experts. Sustainability 2020, 12, 1098. [CrossRef]

31. van der Linden, A.; de Olde, E.M.; Mostert, P.F.; de Boer, I.J. A review of European models to assess the sustainability performance of livestock production systems. Agric. Syst. 2020, 182, 102842. [CrossRef]

32. Bernués, A.; Ruiz, R.; Olaizola, A.; Villalba, D.; Casasús, I. Sustainability of pasture-based livestock farming systems in the European Mediterranean context: Synergies and trade-offs. Livest. Sci. 2011, 139, 44-57. [CrossRef]

33. Lynch, D.; Sumner, J.; Martin, R. Framing the Social, Ecological and Economic Goods and Services Derived from Organic Agriculture in the Canadian Context. In Organic Farming, Prototype for Sustainable Agricultures; Bellon, S., Penvern, S., Eds.; Springer: Dordrecht, The Netherlands, 2014; pp. 347-365.

34. Gómez-Baggethun, E.; Martín-López, B. Ecological economics perspectives on ecosystem services valuation. In Handbook of Ecological Economics; Martínez-Alier, J., Muradian, M., Eds.; Edward Elgar Publishing Limited: Cheltenham, UK, 2015 ; pp. 260-282.

35. Kelemen, E.; Nguyen, G.; Gomiero, T.; Kovács, E.; Choisis, J.P.; Choisis, N.; Herzog, F. Farmers' perceptions of biodiversity: Lessons from a discourse-based deliberative valuation study. Land Use Policy 2013, 35, 318-328. [CrossRef]

36. Bernués, A.; Tello-García, E.; Rodríguez-Ortega, T.; Ripoll-Bosch, R.; Casasús, I. Agricultural practices, ecosystem services and sustainability in High Nature Value farmland: Unraveling the perceptions of farmers and nonfarmers. Land Use Policy 2016, 59, 130-142. [CrossRef] 
37. Teixeira, H.M.; Vermue, A.J.; Cardoso, I.M.; Claros, M.P.; Bianchi, F.J. Farmers show complex and contrasting perceptions on ecosystem services and their management. Ecosyst. Serv. 2018, 33, 44-58. [CrossRef]

38. Smith, H.F.; Sullivan, C.A. Ecosystem services within agricultural landscapes-Farmers' perceptions. Ecol. Econ. 2014, 98, 72-80. [CrossRef]

39. Fernández-Nogueira, D.; Corbelle-Rico, E. Land use changes in Iberian Peninsula 1990-2012. Land 2018, 7, 99. [CrossRef]

40. Chas-Amil, M.L.; García-Martínez, E.; Touza, J. Iberian Peninsula October 2017 wildfires: Burned area and population exposure in Galicia (NW of Spain). Int. J. Disaster Risk Reduct. 2020, 48, 101623. [CrossRef]

41. Díez Díez, J.L. A evolución do Sector Produtor de Leite Cara a Unha Europa sen Cotas Lácteas. Asociación Galega Terra e Leite. Documento $N^{\circ}$ 5. Available online: https: / terraeleite.org/documentos/a-evolucion-do-sector-produtor-de-leite-cara-a-unhaeuropa-sen-cotas-lacteas/ (accessed on 8 July 2021).

42. INE. Encuesta Sobre la Estructura de las Explotaciones Agrícolas; Instituto Nacional de Estadística: Madrid, Spain, 2016.

43. IGE. Instituto Gallego de Estadística. Registro de explotaciones agrarias. Sistema de Trazabilidad Animal. 2019. Available online: https:/ / www.ige.eu/web/mostrar_actividade_estatistica.jsp?idioma=es\&codigo=0301005 (accessed on 8 July 2021).

44. Fernández-Lorenzo, B.; Flores, G.; Botana, A.; Resch, C.; Dagnac, T.; Veiga, M.; Pereira, S.; Lorenzana, R. Estructura productiva y sistemas de alimentación de las explotaciones lecheras de Galicia. Afriga 2016, 124, 98-114. Available online: https: / issuu.com/ transmediacomunicacion/docs/afriga124_castelan_web (accessed on 8 July 2021).

45. Flores-Calvete, G.; Martínez-Fernández, A.; Doltra, J.; García-Rodríguez, A.; Eguinoa-Ancha, P. Informe estructura y sistemas de alimentación de las explotaciones lecheras de Galicia, Cornisa Cantábrica y Navarra; INIA: Madrid, Spain, 2017; pp. 1-52.

46. Salcedo, G. Emisiones en la producción de forrajes de las explotaciones lecheras. ITEA 2020, 116, 311-337. [CrossRef]

47. Rabiee, F. Focus-group interview and data analysis. Proc. Nutr. Soc. 2004, 63, 655-660. [CrossRef] [PubMed]

48. Polit, D.F.; Hungler, B.P. Study Guide for Essentials of Nursing Research: Methods, Appraisal, and Utilization; Lippincott Williams \& Wilkins: Baltimore, MD, USA, 1993.

49. Cameron, J. Focussing on the Focus Group. In Qualitative Research Methods in Human Geography, 2nd ed.; Hay, I., Ed.; Oxford University Press: Melbourne, Australia, 2005; Chapter 8.

50. Yin, R.K. Qualitative Research from Start to Finish; Guilford Publications: New York, NY, USA, 2015.

51. Säynäjoki, E.S.; Heinonen, J.; Junnila, S. The power of urban planning on environmental sustainability: A focus group study in Finland. Sustainability 2014, 6, 6622-6643. [CrossRef]

52. Krueger, R.A.; Casey, M.A. Focus Groups: A Practical Guide for Applied Research, 2nd ed.; SAGE: Thousand Oaks, CA, USA, 2009.

53. E. Fisher. What practitioners consider to be the skills and behaviors of an effective people project manager. Int. J. Proj. Manag. 2011, 29, 994-1002. [CrossRef]

54. Ripoll-Bosch, R.; Díez-Unquera, B.; Ruiz, R.; Villalba, D.; Molina, E.; Joy, M.; Olaizola, A.; Bernués, A. An integrated sustainability assessment of mediterranean sheep farms with different degrees of intensification. Agric. Syst. 2012, 46-56, 46-56. [CrossRef]

55. Dumont, B.; Fortun-Lamothe, L.; Jouven, M.; Thomas, M.; Tichit, M. Prospects from agroecology and industrial ecology for animal production in the 21st century. Animal 2013, 7, 1028-1043. [CrossRef]

56. Foote, K.J.; Joy, M.K.; Death, R.G. New Zealand dairy farming: Milking our environment for all its worth. Environ. Manag. 2015, 56, 709-720. [CrossRef]

57. Villar, A.; Salcedo, G.; Vázquez-González, I.; Suárez, E.; Busqué, J. Is It Possible to Estimate the Composition of a Cow's Diet Based on the Parameters of Its Milk? Sustainability 2021, 13, 4474. [CrossRef]

58. Villar, A.; Vázquez, I.; Collantes, F.; Fernández, E.; Mier, M. Producción de Leche Pasteurizada de Granja en Cantabria. Consejería de Desarrollo Rural, Ganadería, Pesca, Alimentación y Mediambiente; Gobierno de Cantabria: Santander, Cantabria, 2021 ; pp. 1-139.

59. OCDE/FAO. Perspectivas Agrícolas 2019-2028; OECD Publishing: Paris, France, 2019; pp. 1-348.

60. Hughner, R.S.; McDonagh, P.; Prothero, A.; Shultz, C.J.; Stanton, J. Who are organic food consumers? A compilation and review of why people purchase organic food. J. Consum. Behav. Int. Res. Rev. 2007, 6, 94-110. [CrossRef]

61. Olaizola, A.; Bernués, A.; Blasco, I.; Sanz, A. Perspectiva de una carne de calinda differentiated: Análisis exploratorio para la carne de vacuno Serrana de Teruel. ITEA 2012, 108, 546-562.

62. Beudou, J.; Martin, G.; Ryschawy, J. Cultural and territorial vitality services play a key role in livestock agroecological transition in France. Agron. Sustain. Dev. 2017, 37, 36. [CrossRef]

63. López-Iglesias, E. O sector agrario e agroalimentario en Galicia; balance das transformacións desde a integración europea, 1986-2016. Rev. Galega Econ. 2019, 28, 1-20. [CrossRef]

64. Mills, K.E.; Weary, D.M.; von Keyserlingk, M.A.G. Graduate Student Literature Review: Challenges and opportunities for human resource management on dairy farms. J. Dairy Sci. 2021, 104, 1192-1202. [CrossRef]

65. Botana, A.; Suárez, B.; Resch, C.; Ribas, A.; López, E.; Sánchez, A.; Peón, D.; Ruiz, F.; López, E. Estratexia de Dinamización do Sector Lácteo Galego 2020-2025; Transmedia Comunicación y Prensa: Lugo, Spain, 2020; pp. 1-394.

66. Cooper, T.; Hart, K.; Baldock, D. Provision of Public Goods through Agriculture in the European Union; Institute for European Environmental Policy: London, UK, 2009.

67. Valladares, J.; Pereira-Crespo, S.; Flores, G.; Díaz, N.; Fernández-Lorenzo, B.; Resch, C.; Piñeiro, J. New annual legumes as winter crops for intensive forage rotations in Galicia (NW Spain). In Proceedings of the 14th Meeting of the FAOCIHEAM Sub-Network on Mediterranean Pastures and Fodder Crops, Samsun, Turkey, 3-6 October 2012.

68. Corbelle, E.; Crecente, R. El abandono de tierras: Concepto teórico y consecuencias. Rev. Galega Econ. 2008, 17, 1-15. 
69. Van Oudenhoven, A.P.; Petz, K.; Alkemade, R.; Hein, L.; de Groot, R.S. Framework for systematic indicator selection to assess effects of land management on ecosystem services. Ecol. Indic. 2012, 21, 110-122. [CrossRef]

70. Rodríguez-Morales, B.; Roces-Díaz, J.V.; Kelemen, E.; Pataki, G.; Díaz-Varela, E. Perception of ecosystem services and disservices on a peri-urban communal forest: Are landowners' and visitors' perspectives dissimilar? Ecosyst. Serv. 2020, $43,101089$. [CrossRef]

71. Shah, S.M.; Liu, G.; Yang, Q.; Wang, X.; Casazza, M.; Agostinho, F.; Giannetti, B.F. Emergy-based valuation of agriculture ecosystem services and dis-services. J. Clean. Prod. 2019, 239, 118019. [CrossRef]

72. Wiesner, S.; Duff, A.J.; Desai, A.R.; Panke-Buisse, K. Increasing Dairy Sustainability with Integrated Crop-Livestock Farming. Sustainability 2020, 12, 765. [CrossRef]

73. Scarascia-Mugnozza, G.; Sica, C.; Russo, G. Plastic materials in European agriculture: Actual use and perspectives. J. Agric. Eng. 2011, 42, 15-28. [CrossRef]

74. SIRGA. Sistema de Recollida de Plásticos Agrícolas. Available online: https://sirga.xunta.gal/recollida-plasticos-agricolas (accessed on 8 July 2021).

75. Alem, H. Performance of the Norwegian dairy farms: A dynamic stochastic approach. Res. Econ. 2020, 74, 263-271. [CrossRef]

76. Andrade, D.; Pasini, F.; Scarano, F.R. Syntropy and innovation in agriculture. Curr. Opin. Environ. Sustain. 2020, 45, 20-24. [CrossRef]

77. Moreno-Pérez, O.M.; Arnalte-Alegre, E.; Ortiz-Miranda, D. Breaking down the growth of family farms: A case study of an intensive Mediterranean agriculture. Agric. Syst. 2011, 104, 500-511. [CrossRef]

78. Giner, S.C.; Pujol-Andreu, J.; Pan-Montojo, J. Innovación y cambio técnico en la agricultura. Hist. Agrar. Rev. Agric. Hist. Rural 2002, 27, 15-42.

79. Thissen, F.; Fortuijn, J.D.; Strijker, D.; Haartsen, T. Migration intentions of rural youth in the Westhoek, Flanders, Belgium and the Veenkoloniën, The Netherlands. J. Rural Stud. 2010, 26, 428-436. [CrossRef]

80. Rodríguez-Bermúdez, R.; Miranda, M.; Fouz, R.; Orjales, I.; Diéguez, F.J.; Minervino, A.H.H.; López-Alonso, M. Breed performance in organic dairy farming in Northern Spain. Reprod. Domest. Anim. 2020, 55, 93-104. [CrossRef] [PubMed]

81. Strzepek, K.; Boehlert, B. Competition for water for the food system. Philos. Trans. R. Soc. B Biol. Sci. 2010, 365, 2927-2940. [CrossRef]

82. Vázquez-González, I.; García-Arias, A.; Pérez-Fra, M.; Valdês-Paços, B.; López-Iglesias, E. A shared diagnosis of the current situation of Galician dairy farming: A bottom-up approach. In Proceedings of the XVI EAAE Virtual Congress, Prague, Czech Republic, 20-23 July 2021.

83. Europen Commission. A Farm to Fork Strategy for a Fair, Healthy and Environmentally-Friendly Food System; Europen Commission: Brussels, Belgium, 2020. 